\title{
Isolation of Leishmania infantum, Zymodeme MON-1 from Canine and Human Visceral Leishmaniasis on Margarita Island, Venezuela
}

\author{
Olga Zerpa/ ${ }^{+}$, Francine Pratlong* , Marian Ulrich, Jacinto Convit \\ Instituto de Biomedicina, Universidad Central de Venezuela, Apartado postal 4043 (Esquina San Nicolás, San \\ José), Caracas 1010A, Venezuela *Centre Nacional de Reference sur les Leishmanioses, Centre Hospitalier- \\ Universitaire, Montpellier, France
}

An increase in the incidence of human visceral leishmaniasis $(H V L)$ has been detected in recent years on Margarita Island, located off the NE coast of Venezuela. Recent studies have revealed reactivity to rK39 antigen (Leishmania chagasi) in $20 \%$ of 541 sera from domestic dogs in endemic communities; PCR reactions were positive using primers for the $\mathrm{L}$. donovani complex. Here we report that isolates from human and canine infection, identified by isoenzyme analysis, correspond to $\mathrm{L}$. infantum, zymodeme MON-1. This appears to be the first isolation and identification of an isolate from HVL on Margarita Island and demonstrates the presence of this zymodeme in the canine population.

Key words: visceral leishmaniasis - Leishmania infantum MON-1 - Venezuela

Margarita Island, with a population of 384,800 inhabitants, occupies an area of $1085 \mathrm{~km}^{2}$ off the northeastern coast of Venezuela. Recent studies of American visceral leishmaniasis (AVL) on the Island have shown a relatively small but increasing number of human cases in recent years; the vast majority occurred in children three years old or younger. In spite of the relatively low frequency of human infection, serological studies (ELISA) of 541 canine sera with highly specific recombinant K39 antigen (Burns Jr et al. 1993), originally derived from Leishmania chagasi and kindly donated by Dr Steven Reed, Corixa Corporation, Seattle, WN, USA, revealed infection in $20 \%$ of the dogs sampled from eight peri-urban and rural endemic areas where human cases have been reported (Zerpa et al. 2000). This observation reveals the presence of a potentially volatile zoonotic epidemiological situation that may have increasingly unfavorable repercusions on the human population because of economic recession in the area, climatic variations af-

Financial support by the World Bank/Government of Venezuela Program for the Control of Endemic Diseases, grant VEN/96/002-021-025.

${ }^{+}$Corresponding author. Fax: 58-212-8611258. E-mail: ozerpa@telcel.net.ve

Received 6 December 2000

Accepted 2 July 2001 fecting vector density and other undefined risk factors.

During the investigation on Margarita Island, parasites were isolated from human cases and serologically positive dogs by inoculation of infected samples onto Difco blood agar slants containing $10 \%$ of defibrinated rabbit blood and $50 \mu \mathrm{g}$ of gentamicin/ml or by intraperitoneal inoculation of necropsy samples or first-passage cultures into golden hamsters. Many isolates initially grew vigorously in culture media but were lost on subsequent subculture. Hamster infections were characterized by marked hepato-splenomegaly or gross enlargement of either the liver or spleen, with enormous numbers of amastigotes in Giemsa-stained imprints; neither accumulation of ascitic fluid nor other physical changes were noted at necropsy.

Our previous study of blood and tissue samples from patients and canines revealed a characteristic PCR product of about 800 base pairs with primers described by Smyth et al. (1992), which are specific for the L. donovani complex. Two isolates, one from a bone marrow aspirate from a two-year-old girl and the other from bone marrow taken at necropsy from an infected dog, have now been identified by enzyme analysis after electrophoresis on starch gels with a panel of 15 enzymes (Rioux et al. 1990) at the Centre Nacional de Reference sur les Leishmanioses, Director Jean-Pierre Dedet, Montpellier by one of the authors of this communication (FP). Both isolates, MHOM/VE/98/NESA and MCAN/VE/98/IBO-78, correspond to $L$. infantum, zymodeme MON-1. 
To our knowledge, the only previous classification of an isolate of Leishmania from Margarita Island was reported by Delgado et al. (1993). These authors reported that a culture which had been maintained for many years of an isolate from the bone marrow of a dog on Margarita Island, as well as another isolate from a case of HVL from Aragua State in north-central Venezuela, were identified by starch gel electrophoretic isoenzyme analysis as $L$. colombiensis. The three enzymes which permit discrimination between $L$. colombiensis and all other species of Leishmania, mannose phosphate isomerase, E.C.5.3.1.8; glucose phosphate isomerase, E.C. 5.3.1.9 and glucose-6-phosphate dehydrogenase, E.C.1.1.49 (Kreutzer et al. 1991), form part of the panel of enzymes used in the present study. L. colombiensis, a member of the $L$. braziliensis complex, is most frequently associated with cutaneous infection; it does not produce infection in hamsters inoculated subcutaneously (Kreutzer et al. 1991). The biological and biochemical characteristics of the isolates from Margarita Island that we have studied recently are clearly distinct from L. colombiensis. No autochthonous cases of cutaneous leishmaniasis have been reported on the Island.

More than a decade ago, isolates of Leishmania from human cases and dogs from Trujillo State in western mainland Venezuela were identified as $L$. infantum, zymodeme MON-1, based on the study of 15 enzymes by starch gel electrophoresis (Moreno et al. 1986, 1990). The current study confirms the presence of this zymodeme in a geographically distant, insular of the country and would suggest that this zymodeme is widely distributed in Venezuela.

\section{ACKNOWLEDGEMENTS}

To P Lami, Montepellier, and M Centeno, Caracas, for technical assistance.

\section{REFERENCES}

Burns Jr JM, Sheffler WG, Bensen DR, Ghalib HW, Badaró R, Reed SG 1993. Molecular characterization of a kinesin-related antigen of Leishmania chagasi that detects specific antibody in African and American visceral leishmaniasis. Proc Natl Acad Sci USA 90: 775-779.

Delgado O, Castés M, White AC, Kreutzer RD 1993. Leishmania colombiensis in Venezuela. Am J Trop Med Hyg 48: 145-147.

Kreutzer RD, Corredor A, Grimaldi G, Grogl M, Rowton ED, Young DG, Morales A, McMahon-Pratt D, Guzman H, Tesh RB 1991. Characterization of Leishmania colombiensis sp.n (Kinetoplastida: Trypanosomatidae), a new parasite infecting humans, animals, and phlebotomine sand flies in Colombia and Panama. Am J Trop Med Hyg 44: 662-675.

Moreno G, Scorza JV, Añez N 1990. Leishmania infantum en el estado Trujillo, Venezuela. Acta Cient Vene 41 (Supl. 1): 27.

Moreno G, Rioux J-A, Lanotte G, Pratlong F, Serres E 1986. Le complexe Leishmania donovani s.1. Analyse enzymatique et traitment numérique. Individualisation du complexe Leishmania infantum. Corollaires biogéographiques et phylétiques. A propos de 146 souches originaires de l'Ancien et du Nouveau Monde. In Coll Int CNRS/INSERM 1984, Leishmania. Taxonomie et Phylogenése. Applications éco-épidémiologiques, IMEEE, Montpellier, p. 105117.

Rioux JA, Lanotte G, Serres E, Pratlong F, Bastien P, Perieres J 1990. Taxonomy of Leishmania. Use of isoenzymes. Suggestions for a new classification. Ann Parasitol Hum Comp 65: 111-124.

Smyth AJ, Ghosh A, Hassan MQ, Basu D, De Bruijn MHL, Adhya S, Mallik KK, Barker DC 1992. Rapid and sensitive detection of Leishmania kinetoplast DNA from spleen and blood samples of kala-azar patients. Parasitology 105: 183-192.

Zerpa O, Ulrich M, Negrón E, Rodríguez N, Centeno M, Rodríguez V, Barrios RM, Belizario D, Reed S, Convit J 2000. Canine visceral leishmaniasis on Margarita Island (Nueva Esparta, Venezuela). Trans $R$ Soc Trop Med Hyg 94: 484-487. 